\title{
An Investigation of Social Factors in Children's Foreign Language Learning-A Case Study of Taiwanese Elementary School Students
}

\author{
Yen-Ju Hou \\ Shu-Zen Junior College of Medicine and Management, Kaohsiung, Taiwan \\ Email: yenju0228@gmail.com
}

Received 23 February 2015; accepted 24 March 2015; published 30 March 2015

Copyright (C) 2015 by author and Scientific Research Publishing Inc.

This work is licensed under the Creative Commons Attribution International License (CC BY). http://creativecommons.org/licenses/by/4.0/

\section{(c) (i) Open Access}

\begin{abstract}
Social factors are believed to play a crucial role in language learning and have a major impact on second/foreign language proficiency (Ellis, 2003). The study was conducted to investigate Taiwanese children's English learning motivation/attitude and the impacts of social factors of age, gender and social class on their English learning. Participants were 520 students from 6 elementary schools near Tainan City, divided into two groups as Urban Group $(\mathrm{N}=271)$ and Rural Group ( $N=249$ ) based on their schools' location. All were arranged to fill out a questionnaire dealing with their background and English learning motivation/attitude (Gardner, 1985). All available data were processed by SPSS $\mathbf{1 7 . 0}$ for descriptive, correlation, ANOVA, and predictive analyses. It was expected that the findings could provide more understanding about how social factors affect children's second/foreign language learning, and to unlock the potential of the rural students when it comes to the tenth year of the official implementation of English teaching in Taiwanese elementary schools.
\end{abstract}

Keywords

Age, Gender, Social Class, Motivation, Attitude

\section{Introduction}

As in a global village, English has become the "Lingua Franca" and been widely used as a tool for communication in many fields. To promote the English skills of its workforce and economic outlook, many countries have 
invested enormous resources in English language learning, and Taiwan is not an exception. One of the efforts and changes made was the nation-wide implementation of English teaching for the elementary school students in 2005, starting from the third graders upward, though, not until 2010, was English officially included in the curriculum for the fifth and sixth grades in elementary schools. Based on The Nine-year Integrated Curriculum for Elementary and Junior High Schools Guidelines, the goals of English curriculum are 1) to help students develop basic communication skills in English; 2) to cultivate students' interests in learning English; and 3) to promote students' awareness of local and foreign cultures and customs (Ministry of Education, Taiwan, 2000). Consequently, the English instructions at the elementary stage are placed on developing students' listening and speaking abilities in the first two years with approximately 1 - 2 hours a week, and gradually integrating reading and writing skills, in the following two years with approximately 2 hours a week. Now, it comes to the tenth year of the official implementation of English instruction in the elementary schools. The process still has some pros and cons. Some crucial concerns include the differences of students' learning motivation, English prior knowledge, rural/urban areas, teachers, resources, performance, etc. Second/foreign language learning is a complex process, and is affected by many factors. Among them, social factors are believed to play a crucial role in the learning process and outcome. Hence, the study aimed to investigate, from a social aspect to see how gender, age, and social class influence students’ English learning motivation and attitude.

\subsection{The Research Questions}

The study intended to answer the following research questions:

1) What are Taiwanese elementary school students' English learning motivation and attitude?

2) How gender, age, and social class influence their English learning motivation and attitude?

\subsection{Purposes of the Study}

The study was a step toward providing a better understanding of 1) Taiwanese elementary school students' English learning motivation and attitude and 2) how gender, age, and social class influence their English learning motivation and attitude.

\section{Literature Review}

Related studies of gender, age, social class, motivation, and attitude in second/ foreign language learning were described below:

\subsection{Gender}

The role of gender in language learning has been discussed very often. Many research findings have revealed that female students perform better than male students in foreign language learning. Ellis (2003) claimed that gender is one of the social factors that affect L2 learning. Much earlier, Gardner and Lambert (1972) reported that female learners of L2 French in Canada were more motivated and hold more positive attitudes than male learners. Other findings showed that gender played a role in influencing the kinds of strategy used, preferred learning styles (Hou, 2009; Good \& Brophy, 1986), and made a significant difference in language learning (Hou et al., 2010). In general, it was found that female students used compensation and affective strategies significantly more often than male students, for example, Burstall (1975) found that the girls scored significantly higher than the boys on all tests measuring achievement in French throughout the period of the study. The same findings can be found in Boyle's (1987) study of 490 Chinese university students in Hong Kong. The female students achieved higher overall means on ten English proficiency tests. More recently, it was pointed out that genders did differ in multiple intelligences, learning behavior and English performance (Hou, 2014).

\subsection{Age}

Second/foreign language learners begin to acquire the target language at later age than they do their first language. Hence, age is the first explanation of language learners' success. It is believed that "older is faster, but younger is better" (Larsen-Freeman \& Long, 1991: p. 155). Younger learners are at an advantage in achieving accent-free and native like performance (Oyama, 1976; Scovel, 1981; Seliger, 1978). Whereas older learners, 
they are at an advantage in rate of acquisition, and they "proceed through early stages of syntactic and morphological development faster than children” (Krashen et al., 1979). In addition, older learners’ greater cognitive maturity helps "transfer" their first language to the second language. Ellis (2003) made five general conclusions of age issue, including: 1) Adult learners have an initial advantage where rate of learning is concerned, particularly in grammar; 2) Only child learners are capable of acquiring a native accent in informal learning context; 3) Children may be more likely to acquire a native grammatical competence; 4) Irrespective of whether native-speaker proficiency is achieved, children are most likely to reach higher levels of attainment in both pronunciation and grammar than adults; 5) The process of acquiring an L2 grammar is not substantially affected by age, but that of acquiring pronunciation may be (pp. 491-492).

\subsection{Social Class}

An individual's social class can be distinguished into four groups: lower class, working class, lower middle class, and upper middle class, "by means of a composite measure that takes account of income, level of education and occupation" (Ellis, 2003: p. 204). Burstall (1975) found that there was a strong correlation between socio-economic status and achievement for primary and secondary school learners of French as a second language. It was recognized that more children from middle-class homes with better socio-economic status often outperformed those from lower- and working-class homes. In addition, class-related differences also existed in the learners' attitudes toward second/foreign language learning. Many studies also found that children from lower socialeconomic groups were less successful in education than those from higher groups (Olshtain, Shohoamy, Kemp \& Chatow, 1990; Skehan, 1990, 1991). Nevertheless, Ellis (2003) also pointed out that it was not socio-economic class, but rather the experiences of the world which members of the different social classes had, because different life experiences eventually led to different levels of school achievement (Heath, 1983).

\subsection{Motivation and Attitude}

Gardner and Lambert (1959) were the first to publish the investigation of the relationship of attitudes and motivation to second language achievement. It was hypothesized that attitude could play a role in second language acquisition. They suggested two independent factors both related to second language acquisition, namely, language aptitude and motivation. As for motivation, Gardner \& Lambert (1959) began to define it as integrative and instrumental motivations. The former is "based on a desire to become more like valued members of the target language community," (Gardner \& Lambert, 1959: p. 267) and the latter is that "which reflects a determination to acquire another language to achieve such goals as a good job or social recognition" (Clement et al., 1977). It was found that there were clear associations among an integrative orientation, attitudes toward French speaking Canadians, motivational intensity and French achievement. Regarding to attitude, Titone (1990) focused on the role of attitude in second language learning. He indicated that attitudes strictly tied up with motivational dynamics work most powerfully, especially in acquiring mastery in a second language. The causal relationship between attitude and achievement is contradictory. Positive attitude may cause satisfactory achievement. On the other hand, successful achievement may breed positive attitudes. Unlike aptitude, attitudes are not inborn and can be developed and cultivated. In any event, it was suggested that "Developing sound attitudes is the first step toward the achievement of bilingualism” (Titone, 1990: p. 1).

\section{Research Methodology}

A case study was used for the research methodology. That was because it was a bounded system, which was in a particular circumstance and with a particular problem, and also gave readers "space" for their own opinions (Stake, 1988).

\subsection{Subjects}

A total of 520 Taiwanese EFL students participated in the study. They were all the student populations from 6 elementary schools in Tainan City, including 271 males (52\%) and 249 females (48\%). Students were divided into two groups as Urban Group ( $\mathrm{N}=225)(43 \%)$ and Rural Group $(\mathrm{N}=295)(57 \%)$ based on their schools' locations. They were arranged to fill out questionnaire dealing with their background, motivation, attitude and motivational intensity toward English learning. The subjects of the study were shown in Table 1. 
Table 1. Subjects of the study.

\begin{tabular}{cccc}
\hline Gender school & Boy & Girl & Total \\
\hline Urban group & 115 & 110 & $225(43 \%)$ \\
Rural group & 156 & 139 & $295(57 \%)$ \\
Total & $271(52 \%)$ & $249(48 \%)$ & $520(100 \%)$ \\
\hline
\end{tabular}

\subsection{Data Collection Instrument}

The research questionnaire items were mostly adopted from Gardner (1985). For easy to read, the questionnaire items were translated into Chinese, and even with phonetic symbols for the first two graders. The 49-item questionnaire contained 5 items of students' background, 16 items for reasons to learn English, 18 items for attitude, and the rest 10 items for motivational intensity.

Along with descriptive statistics of mean, standard deviation, and percentages of the questionnaire, Pearson Relation Analysis was used to find out if there was any relationship among motivation, attitude and motivational intensity. In addition, an ANOVA was used to find out the differences of the impacts of social factors (age, gender, social class) on motivation and attitude. Lastly, a regression analysis was used to see what social factors (age, genders and social class) were predictive of students' English learning motivation and attitude. All were processed by Statistical Package of Social Science (SPSS, 17). The research instrument of the study was shown in Table 2.

\subsection{Procedure}

To help investigate students' English learning, the researcher was invited by the principals of the six elementary schools in Tainan City. The researcher was also informed by the principals that those subjects who agreed to participate in the study would sign their names on the paper when filling in the questionnaire. Hence, the researcher went to the six schools to collect the data in person in 2013-2014 and received all the 520 valid copies of response. After that, the research results were provided for all the six schools.

\section{Findings and Discussions}

Findings included 1) the reliability of the research instrument; 2) students' background and English learning motivation and attitude, 3)-4) the descriptions and correlation of students' motivation, attitude and motivational intensity; 5)-7) ANOVA analysis of the differences of the impacts of age, genders, and social class on students' English learning behaviors; as well as 8) regression analysis of the factors predicting students' English learning behaviors. The findings were described below.

\subsection{The Reliability of the Research Instrument}

The overall reliability of the questionnaire in the study was Cronbach Alpha $=.941$ ( $\mathrm{N}$ of case $=44)$, with $.869, .896$, and .850 for individual parts of motivation, attitude, and motivational intensity, respectively. "If a test were perfectly reliable, the reliability coefficient would be $1.00 \ldots$...However, no test is perfect reliable" (Gay \& Airasian, 2003: p. 141). Hence, the result indicated that the research instrument of the study was quite reliable.

\subsection{Students' Background and English Learning Behavior}

There were 520 students participating in the study, including 271males (52\%), and 249 females (48\%), with an average age of 8.5 years old, ranging from 6 to 11 . Among the participants, $42.5 \%$ self-reported that they attended extra English programs out of campus more than two years, especially students from rural areas (46.9\%), though rural students had higher mean in attending cram school $(\mathrm{M}=2.21)$ than rural students $(\mathrm{M}=2.11)$. As for family's guiding their English homework, 7.9\% of the students expressed "never", especially students from urban areas $(15.8 \%)(\mathrm{p}<.01)$. Furthermore, regarding to family's social class, more students of urban areas were from higher social class $(M=2.75)$ than those of rural areas $(M=2.34)(p<.01)$. In particular, $41.5 \%$ of the students of rural areas were from "lower class". The findings were shown in Table 3. 
Table 2. Research instrument of the study.

\begin{tabular}{cccc}
\hline Research instrument & Item number & Point \\
\hline Background & Motivation & $2-6$ \\
& Instrumental orientation $^{*}$ & $6-21$ & 5 \\
Questionnaire & Integrative orientation $^{*}$ & $6,8,10,12,14,16,18,20$ & 5 \\
& Attitude $^{*}$ & $7,9,11,13,15,17,19,21$ & 5 \\
& Motivational intensity $^{*}$ & $22-39$ & 3 \\
\hline
\end{tabular}

*Chinese version with phonetic symbols of the questionnaire items 6 - 49 were mostly adopted from Gardner's "Social psychology and second language learning: The role of attitude and motivation" (1985) (Please see the Appendix).

Table 3. Students' background $(\mathrm{N}=520)$.

\begin{tabular}{|c|c|c|c|c|c|c|c|c|}
\hline English learning and parental involvement & Group & $1 \%$ & $2 \%$ & $3 \%$ & $4 \%$ & $5 \%$ & $6 \% / \mathrm{M}$ & \\
\hline & Urban & 51.1 & 48.9 & & & & & \\
\hline \multirow[t]{3}{*}{ 1. Gender___ 1) Male 2) female } & Rural & 52.9 & 47.1 & & & & & \\
\hline & All & 52.1 & 47.9 & & & & & \\
\hline & Urban & 0 & 18.2 & 16.0 & 16.9 & 28.0 & 20.9 & \\
\hline \multirow[t]{3}{*}{ 2. Grade___ 1) $1^{\text {st }}$ 2) $2^{\text {nd }}$ 3) $3^{\text {rd }}$ 4) $4^{\text {th }}$ 5) $5^{\text {th }}$ 6) $6^{\text {th }}$} & Rural & 15.5 & 16.0 & 15.6 & 18.6 & 17.3 & 17.3 & \\
\hline & All & 8.8 & 16.9 & 15.8 & 17.9 & 21.8 & 18.8 & \\
\hline & group & $1 \%$ & $2 \%$ & $3 \%$ & $4 \%$ & & M & sig \\
\hline \multirow{3}{*}{$\begin{array}{l}\text { 3. Attending extra English programs out of school } \\
\text { (such as cram schools) 1) never 2) less than one year } \\
\text { 3) one-two years 4) more than two years }\end{array}$} & Urban & 21.0 & 16.5 & 25.9 & 36.6 & & 2.21 & \multirow{3}{*}{.344} \\
\hline & Rural & 21.1 & 16.7 & 15.3 & 46.9 & & 2.11 & \\
\hline & All & 21.0 & 16.6 & 19.9 & 42.5 & & 2.16 & \\
\hline \multirow{3}{*}{$\begin{array}{l}\text { 4. Family's guiding English homework 1) always 2) sometimes } \\
\text { 3) never }\end{array}$} & Urban & 43.9 & 40.3 & 15.8 & & & 2.71 & \multirow{3}{*}{.000} \\
\hline & Rural & 48.9 & 51.1 & 0 & & & 3.62 & \\
\hline & All & 46.5 & 45.6 & 7.9 & & & 3.23 & \\
\hline \multirow{3}{*}{$\begin{array}{l}\text { 5. Parents' social class 1) upper middle class } \\
\text { 2) lower middle class } 3 \text { ) working class 4) lower class }\end{array}$} & Urban & 29.7 & 24.2 & 37.0 & 8.7 & & 2.75 & \multirow{3}{*}{.000} \\
\hline & Rural & 21.8 & 32.0 & 4.8 & 41.5 & & 2.34 & \\
\hline & All & 25.1 & 28.8 & 18.5 & 27.6 & & 2.51 & \\
\hline
\end{tabular}

\subsection{Description of Students' Motivation, Attitude, and Motivational Intensity}

There was no significant difference between students' instrumental orientation and integrative orientation, but it was found that students of urban areas were more integratively oriented $(M=3.29)$ than students of rural areas $(M=3.07)(p<.01)$. In general, the top five reasons for the students to learn English were: "English seems of great importance today" $(M=3.77)$ (item 20$)$, especially rural students $(\mathrm{p}<.01)$; “To pass exam” $(\mathrm{M}=3.70)$ (item 16); "To promote educational and cultural background" ( $\mathrm{M}=3.65$ ) (item 15); "To be an educated person" ( $M$ = 3.62)(item 10); and "To get a better job” ( $M$ = 3.59) (item 5). In particular, except for 'English seems of great importance today" (item 20), while rural students had higher mean $(\mathrm{p}<.01)$, urban students tended to have significant higher means than rural students in such reasons as "To make friends with foreign language speakers" (item 9) (p < .05); "To think and behave like an English speaking person” (item 11) ( < .01); To leave Taiwan and become a member of American society" (item 13) ( $<$.05); "To study abroad" (item 14) $(\mathrm{p}<.05)$; "To merit social recognition" (item 17) ( $<$.01); and "I like the countries in which English is spoken" (item 19) $(\mathrm{p}<.05)$. 
Regarding to attitudes toward English learning and culture, in general, rural students had higher mean than urban students, though the difference was not significant. Except for more urban students "expect to have more practical teaching material to learn” (item 36) ( $<$.01), rural students held more favorable attitudes toward "English is an international language, everyone should learn English" (item 23) ( $<$.05). On one hand, rural students confessed that they were not really interested in English, they learn it just because it was a required course in school (item 25) ( $<$.01). On the other hand, they wished they could speak English fluently (item 26) $(\mathrm{p}<.01)$. In addition, rural students “expect to have teachers who are native speakers of English” (item 37) $(\mathrm{p}<.01)$; and "hope to study abroad in the summer or winter vacation" (item 39) $(\mathrm{p}<.01)$.

As for motivational intensity, rural students had higher mean $(\mathrm{M}=2.54)$ than urban students $(2.43)(\mathrm{p}<.01)$. Particularly, more rural students would "immediately ask the teacher for help” when they had a problem understanding something in English class (item 41) ( $<$.01); and would always read carefully or rewrite them, correcting their mistakes after they got English assignments back (item 47) ( $<.05)$. But on the contrary, more urban students would actively think about what they had learned in English class (item 44) (p < .01); and if there were a local English TV station, they would try to watch it often (item 49) $(\mathrm{p}<.01)$.

\subsection{The Relations among Motivation, Attitude and Motivational Intensity}

By Pearson Correlation analysis, it was found that motivation, attitude and motivational intensity were strongly and positively correlated to one another $(\mathrm{p}<.01)$. The results were shown in Table 4.

\subsection{Analysis of Gender Differences of Students' Background, Motivation, Attitude, Motivational Intensity, Instrumental Orientation and Integrative Orientation}

The findings revealed that male students had more "parents' guiding homework" than female students (p $<.05)$. Except for that, female students had higher means than male students in all other variables of "attending cram schools”, "parental social class”, "English learning motivation”, “attitude”, "motivational intensity”, “instrumental orientation", and "integrative orientation" (all $\mathrm{p}<.01$ ). The results were shown in Table 5.

Table 4. Relations among motivation, attitude and motivational intensity.

\begin{tabular}{ccccc}
\hline & Motivation & Attitude & Intensity \\
\hline Motivation & Pearson & 1 & $.797\left(^{* *}\right)$ & $.544\left(^{* *}\right)$ \\
& Sig (two tails) & & .000 & .000 \\
Attitude & $\mathrm{N}$ & 501 & 488 & 496 \\
& Pearson & $.797\left(^{* *}\right)$ & 1 & $.631\left(^{* *}\right)$ \\
Sig (two tails) & .000 & & .000 \\
Intensity & Nearson & 488 & 502 & 497 \\
& Sig (two tails) & $.544\left(^{* *}\right)$ & $.631\left(^{* *}\right)$ & .000 \\
$\mathrm{~N}$ & .000 & 496 & 511
\end{tabular}

${ }^{* *} \mathrm{p}<.01$.

Table 5. Analysis of gender differences of background, motivation, attitude, motivational intensity Instrumental orientation, and integrative orientation.

\begin{tabular}{ccccccccccc}
\hline Gender & Number & Cram school & Home work & Social class & Motivation & Attitude & Intensity & Instrumental & Integrative \\
\hline Male & 271 & 2.24 & $\mathbf{2 . 3 9}$ & 2.54 & 3.14 & 3.12 & 2.21 & 3.28 & 3.00 \\
Female & 249 & $\mathbf{2 . 5 8}$ & 2.26 & $\mathbf{2 . 9 0}$ & $\mathbf{3 . 4 8}$ & $\mathbf{3 . 5 8}$ & $\mathbf{2 . 4 8}$ & $\mathbf{3 . 6 2}$ & $\mathbf{3 . 3 4}$ \\
All & 520 & 2.40 & 2.33 & 2.72 & 3.31 & 3.34 & 2.34 & 3.45 & 3.16 \\
Sig & & $\mathbf{. 0 0 1}$ & $\mathbf{. 0 3 3}$ & $\mathbf{. 0 0}$ & $\mathbf{. 0 0 0}$ & $\mathbf{. 0 0 0}$ & $\mathbf{. 0 0 0}$ & $\mathbf{. 0 0 0}$ & $\mathbf{. 0 0 0}$ \\
\hline
\end{tabular}




\subsection{Analysis of Grade/Age Differences of Students' Background, Motivation, Attitude, Motivational Intensity, Instrumental Orientation, and Integrative Orientation}

Regarding to grade/age differences, there was only a significant difference existing in parents' guiding homework ( $\mathrm{p}<.01)$. Particularly, second graders had parents' guiding homework most, while the fourth graders had least. Except for that, none of the other differences reached significant levels, but sixth graders attended cram schools most, both third graders and fourth graders had the highest parental social class, as well as fourth graders were highest in English learning motivation, attitude, motivational intensity, instrumental orientation, and integrative orientation. The results were shown in Table 6.

\subsection{Analysis of Social Class Differences of Students' Background, Motivation, Attitude, Motivational Intensity, Instrumental Orientation, and Integrative Orientation}

In light of social class, significant differences only existed in attending cram schools $(p<.01)$ and integrative orientation $(\mathrm{p}<.01)$. Obviously, urban students attended cram schools more $(\mathrm{p}<.01)$ and became more integratively orientated $(\mathrm{p}<.01)$ than rural students. Though rural students had higher means than urban students in parents' guiding homework, English learning attitude and motivational intensity, the differences didn’t reach significant levels. The results were shown in Table 7.

\subsection{Regression Analysis of Factors Predicting Students' Motivation, Attitude, Motivational Intensity, Instrumental Orientation, and Integrative Orientation}

The findings showed that gender was significantly predictive of all the dependent variables (motivation, attitude, motivational intensity, instrumental orientation, and integrative orientation) (all $\mathrm{p}<.01$ ). In addition, grade/age was negatively predictive of attitude and motivational intensity (both $\mathrm{p}<.05$ ), while attending cram school was predictive of motivation ( $p<.01)$, attitude $(\mathrm{p}<.05)$, instrumental orientation $(\mathrm{p}<.05)$, and integrative orientation ( $\mathrm{p}<.01)$. Furthermore, parents' guiding homework was predictive of motivation $(\mathrm{p}<.05)$, attitude $(\mathrm{p}<.01)$ and motivational intensity $(\mathrm{p}<.01)$. Lastly, parental social class was predictive of motivation and motivational intensity (both $\mathrm{p}<.05$ ), as well as instrumental orientation and integrative orientation (both $\mathrm{p}<.01$ ). The results were shown in Table 8.

Table 6. Analysis of grade/age differences of background, motivation, attitude, motivational intensity, instrumental orientation, and integrative orientation.

\begin{tabular}{cccccccccc}
\hline Grade/age & Number & Cram school & Home work & Social class & Motivation & Attitude & Intensity & Instrumental & Integrative \\
\hline $1^{\text {st }} / 6$ yrs & 35 & 1.60 & 2.20 & 2.62 & 3.14 & 3.45 & 2.37 & 3.43 & 2.86 \\
$2^{\text {nd }} / 7$ yrs & 90 & 1.68 & $\mathbf{2 . 5 4}$ & 2.62 & 3.33 & 3.47 & 2.41 & 3.52 & 3.13 \\
$3^{\text {rd }} / 8$ yrs & 83 & 2.33 & 2.21 & $\mathbf{2 . 8 2}$ & 3.24 & 3.27 & 2.30 & 3.35 & 3.13 \\
$4^{\text {th }} / 9$ yrs & 95 & 2.55 & 2.19 & $\mathbf{2 . 8 2}$ & $\mathbf{3 . 4 5}$ & $\mathbf{3 . 5 0}$ & $\mathbf{2 . 4 4}$ & $\mathbf{3 . 5 7}$ & $\mathbf{3 . 3 3}$ \\
$5^{\text {th }} / 10$ yrs & 115 & 2.70 & 2.38 & 2.68 & 3.27 & 3.30 & 2.25 & 3.43 & 3.12 \\
$6^{\text {th }} / 11$ yrs & 99 & $\mathbf{2 . 9 1}$ & 2.37 & 2.68 & 3.30 & 3.24 & 2.28 & 3.37 & 3.21 \\
All & 517 & 2.40 & 2.33 & 2.69 & 3.30 & 3.24 & 2.34 & 3.45 & 3.16 \\
Sig & & .202 & $\mathbf{. 0 0 1}$ & .565 & .261 & .152 & $\mathbf{. 1 0 8}$ & $\mathbf{. 3 6 3}$ & $\mathbf{. 1 6 2}$ \\
\hline
\end{tabular}

Table 7. Analysis of social class differences of background, motivation, attitude, motivational intensity, instrumental orientation, and integrative orientation.

\begin{tabular}{|c|c|c|c|c|c|c|c|c|}
\hline Social class & Number & Cram school & Home work & Motivation & Attitude & Intensity & Instrumental & Integrative \\
\hline Urban group & 225 & 2.78 & 2.28 & 3.38 & 3.32 & 2.33 & 3.46 & 3.29 \\
\hline Rural group & 295 & 2.11 & 2.37 & 3.25 & 3.70 & 2.35 & 3.43 & 3.07 \\
\hline All & 520 & 2.40 & 2.33 & 3.31 & 3.34 & 2.34 & 3.45 & 3.16 \\
\hline Sig & & .000 & .127 & .073 & .489 & .724 & .675 & .004 \\
\hline
\end{tabular}


Table 8. Regression analysis summary for factors predicting students’ motivation, attitude, motivational intensity, instrumental orientation, and integrative orientation.

\begin{tabular}{cccccccccccc}
\hline Factor & $\mathrm{t}$ & $\mathrm{Sig}$ & $\mathrm{t}$ & $\mathrm{Sig}$ & $\mathrm{t}$ & $\mathrm{Sig}$ & $\mathrm{t}$ & Sig & $\mathrm{t}$ & Sig \\
\hline (Constant) & 11.318 & $\mathbf{. 0 0 0}$ & 11.335 & $\mathbf{. 0 0 0}$ & 15.791 & $\mathbf{. 0 0 0}$ & 44.454 & $\mathbf{. 0 0 0}$ & 9.951 & $\mathbf{. 0 0 0}$ \\
Gender & 4.543 & $\mathbf{. 0 0 0}$ & 6.930 & $\mathbf{. 0 0 0}$ & 6.832 & $\mathbf{. 0 0 0}$ & 3.270 & $\mathbf{. 0 0 1}$ & 3.226 & $\mathbf{. 0 0 1}$ \\
Grade & -.058 & .953 & -2.592 & $\mathbf{. 0 1 0}$ & -2.418 & $\mathbf{. 0 1 6}$ & -1.712 & .088 & 0.47 & .963 \\
Cram school & 2.736 & $\mathbf{. 0 0 6}$ & 1.976 & $\mathbf{. 0 4 9}$ & .707 & .480 & 2.451 & $\mathbf{. 0 1 5}$ & 3.641 & $\mathbf{. 0 0 0}$ \\
Homework & 2.171 & $\mathbf{. 0 3 0}$ & 3.566 & $\mathbf{. 0 0 0}$ & 4.510 & $\mathbf{. 0 0 0}$ & -.848 & .397 & -1.725 & .085 \\
Social class & 2.082 & $\mathbf{. 0 3 8}$ & 1.605 & .109 & 2.255 & $\mathbf{. 0 2 5}$ & 6.096 & $\mathbf{. 0 0 0}$ & 3.059 & $\mathbf{. 0 0 2}$ \\
Dependent variables & Motivation & attitude & Motivational intensity & Instrumental & orientation & Integrative \\
\end{tabular}

\subsection{Discussions}

The study found that elementary school students had favorable English learning behaviors, but there was no significant difference between instrumental orientation and integrative orientations. The finding was quite different from some previous studies indicating that Taiwanese students were more instrumentally motivated (Hou et al., 2011, 2013, and Yang et al., 2013). The possible explanation was that the subjects of the previous studies were either high school students or college students, while the subjects of the present study were elementary school students who had less pressure of English test-taking.

Similar to most of the previous studies, female learners had stronger motivation, more positive attitude and motivational intensity than male learners. As for social class did matter with parental attitude toward guiding children's homework; as in Asian society, male students tend to have more chances to receive parents' guiding homework. In addition, more children from middle-class homes with better socio-economic had stronger motivation, in particular, integrative orientation, more positive attitude, and favorable motivational intensity. The finding supported some other studies indicating that children from lower social-economic groups were less successful in education than those from higher groups (Olshtain et al, 1990, Skehan, 1990, 1991).

\section{Limitations of the Study}

There were two limitations of the study. They were:

1) The participants were from six elementary schools in Tainan, a southern city in Taiwan. The results of the study might be different from that of other parts in the island.

2) The information available here was based on students' self-reported data via school teachers' instruction and explanation in class. Students might either tend to answer the questions in terms of what seemed to be a socially acceptable response, or what they thought the teachers would like them to answer. Furthermore, the result would not be included in their academic transcripts; hence some might not be serious enough in answering the questions. Hence, all might influence the research results to some extent.

\section{Conclusion and Implication}

Some conclusions and implications derived from the study were described below:

\subsection{Conclusion}

1) The research instrument of the study was quite reliable (Cronbach's Alpha $=.941$ ).

2) Among the 520 participants, $43 \%$ were from "urban area", with more integrative orientation; while $42 \%$ of the rest "rural areas" were from "lower class".

3) Male students had more "parents' guiding homework". Except for that, female students had significant higher means than male students in all other variables of "attending cram schools", "parental social class", "English learning motivation”, "attitude”, "motivational intensity”, "instrumental orientation”, and "integrative orientation”. 
4) The seniors (sixth graders) who would graduate and study in junior high schools were found to have less favorable English learning behaviors than the fourth graders, which needs to be paid attention.

\subsection{Implication}

1) The study supported that in the Chinese society boys were still favored by parents and provided more guiding with homework. But girls were found to be more actively participating in cram schools, were motivated both instrumentally and integratively and held positive attitude and favor motivational intensity.

2) The senior students (sixth graders) attended the cram schools more than other graders, but they didn't perform best in their English learning behaviors, including motivation, attitude, and motivational intensity. In fact, their performances were worse than that of fourth graders. So, it was suggested that senior students should be encouraged to enhance their English learning behaviors.

3) In the study, social class was found to be positively predictive of students' motivation, including instrumental orientation and integrative orientation, as well as motivational intensity. Students from urban areas had higher socio-economic status. The findings revealed that they not only had more chances to attend extra English programs out of campus but also were more integratively motivated to learn English than students from rural areas. On the contrary, students from rural areas were with lower socio-economic status. However, they were very potential. They had higher means in attitude and motivational intensity toward English learning, though the differences didn't reach significant levels.

4) Last but not least, how to unlock the potential of the rural students when it comes to the tenth year of the official implementation of English teaching in Taiwanese elementary schools should be the priority of Taiwanese policy-makers, educators, parents, and teachers.

\section{References}

Boyle, J. (1987). Sex differences in Listening Vocabulary. Language learning, 37, 273-284. http://dx.doi.org/10.1111/j.1467-1770.1987.tb00568.x

Burstall, C. (1975). Factors Affecting Foreign-Language Learning: A Consideration of Some Relevant Research Findings. Language Teaching and Linguistic Abstracts, 8, 105-125.

Clement, R., Major, L., Gardner, R. C., \& Smythe, P. C. (1977). Attitudes and Motivation in Second Language Acquisition: An Investigation of Fontario Francophones. Working Papers on Bilingualism, 12, 1-20.

Ellis, R. (2003). The Study of Second Language Acquisition (10th ed.). Oxford: Oxford University Press.

Gardner, R. C., \& Lambert, W. E. (1959). Motivational Variables in Second Language Acquisition. Canadian Journal of Psychology, 13, 266-272. http://dx.doi.org/10.1037/h0083787

Gardner, R. C., \& Lambert, W. E. (1972). Attitude and Motivational in Second Language Learning. Rowley, MA: Newbury House Publishers.

Gardner, R. C. (1985). Social Psychology and Second Language Learning: The Role of Attitude and Motivation. Baltimore, MD: Edward Arnold.

Gay, L. R., \& Airasian (2003). Educational Research: Competencies for Analysis and Applications (7th ed.). Upper Saddle River, NJ: Merrill/Prentice Hall.

Good, T. L., \& Brophy, J. E. (1986). Educational Psychology (3rd ed.). New York, NY: Longman.

Heath, B. (1983). Ways with Words: Language, Life and Work in Communities and Classrooms. Cambridge: Cambridge University Press.

Hou, Y. A. (2009). An Investigation of Perceptual Learning Style Preferences, Language Learning Strategy Use, and English Achievement-A Case Study of Taiwanese EFL Students. Unpublished Doctoral Dissertation, Riverside, CA: La Sierra University.

Hou, Y. J., Hou, Y. A., \& Cheng, H. Y. (2013). Are Skill and Will Predictive to Taiwanese College Students' English Learning? Journal of National United University, 10, 17-42.

Hou, Y. A., Hou, Y. J., Chung, W. Y., \& Cheng, H. Y. (2010). Gender Differences in Multiple Intelligences, Learning Behavior and English Performance. The International Journal of the Humanities, 8, 255-270.

Hou, Y. A., Hou, Y. J., Lee, F. M., Chung, W. Y., \& Cheng, H. Y. (2011). Taiwanese High School Students’ Learning Behaviors, Multiple Intelligences, and English Performance. Oxford Journal, 8, 87-114.

Krashen, S. M., Long, M., \& Scarcella, R. (1979). Age, Rate, and Eventual Attainment in Second Language Acquisition. TESOL Quarterly, 13, 573-582. 
Larsen-Freeman, D., \& Long, M. (1991). An Introduction to Second Language Acquisition Research. London: Longman.

Ministry of Education, Taiwan (2000). The Nine-Year Joint Curricula Plan Language Arts Guidelines for Elementary and Junior High Schools. (In Chinese) http://teach.eje.edu.tw/

Olshtain, E., Shohamy, E., Kemp, J., \& Chatow, R. (1990). Factors Predicting Success in EFL among Culturally Different Learners. Language learning, 40, 23-44. http://dx.doi.org/10.1111/j.1467-1770.1990.tb00953.x

Oyama, S. (1976). A Sensitive Periods in the Acquisition of a Non-Native Phonological System. Journal of Psycholinguistic Research, 5, 261-285. http://dx.doi.org/10.1007/BF01067377

Scovel, T. (1981). The Recognition of Foreign Accents in English and Its Implications for Psycholinguistic Theories of Language Acquisition. In J. G. Savard, \& L. Laforge (Eds.), Proceedings of the 5th Congress of AILA (pp. 389-401). Laval, Canada: University of Laval Press.

Seliger, H. (1978). Implications of a Multiple Critical Periods Hypothesis for Second Language Learning. In W. C. Ritchie (Ed.), Second Language Acquisition Research. Issues and Implications (pp. 11-19). New York: Academic Press.

Skehan, P. (1990). The Relationship between Native and Foreign Language Learning Ability: Educational and Linguistic Factors. In H. Dechert (Ed.), Current Trends in European Second Language Acquisition Research (pp. 83-106). Clevedon: Multilingual Matters.

Skehan, P. (1991). Individual Differences in Second Language Learning. Studies in Second Language Acquisition, 13, 275298. http://dx.doi.org/10.1017/S0272263100009979

Stake, R. E. (1988). Case Study Methods in Educational Research: Seeking Sweet Water. In R. M. Jaeger (Ed.), Complementary Methods for Research in Education (pp. 253-300). Washington DC: American Educational Research Association.

Titone, R. (1990). A Psycho-Sociolinguistic Perspective in EFL Learning: The Role of Attitude a Dynamic Factor. Proceedings of the 9th World Congress of Applied Linguistics, Thessaloniki, 15-21 April 1990, ERIC Document Resume, ED 326073.

Yang, M. T., \& Cheng, H. Y. (2013). Nursing Students' Motivation and Attitude. Proceedings of the Shanghai International Conference on Social Science, Shanghai, 11-13 July 2013. 
Appendix: Questionnaire

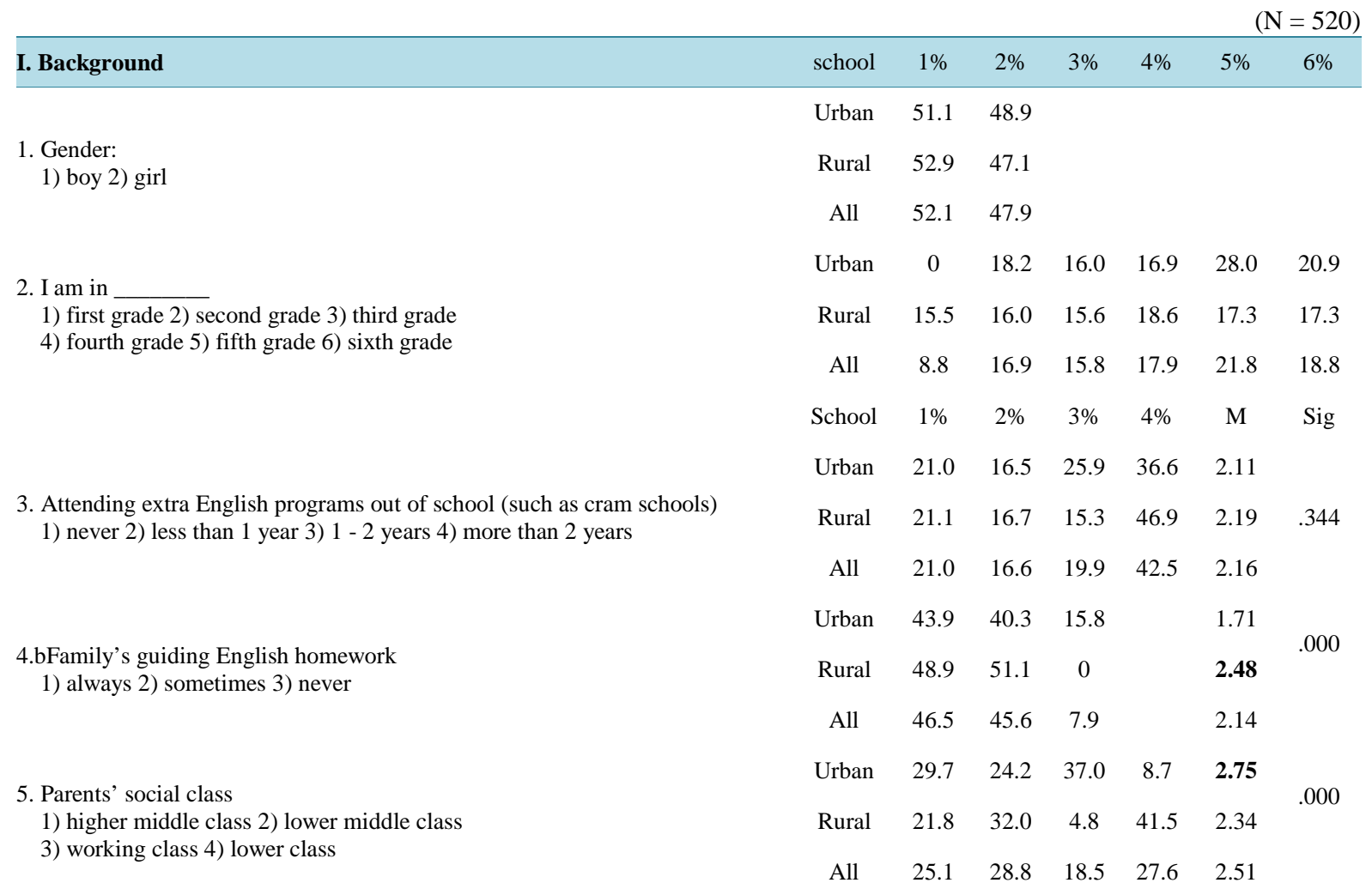

\section{Orientation Index: Reasons for studying English}

1 = strongly disagree $2=$ disagree $3=$ no comment 4 = agree $5=$ strongly agree

\section{Contents}

6. To fulfill a school requirement.

7. To understand English speaking people and their way of life.

8. To get a better job.

9. To make friends with foreign language speakers.

10. To be an educated person.

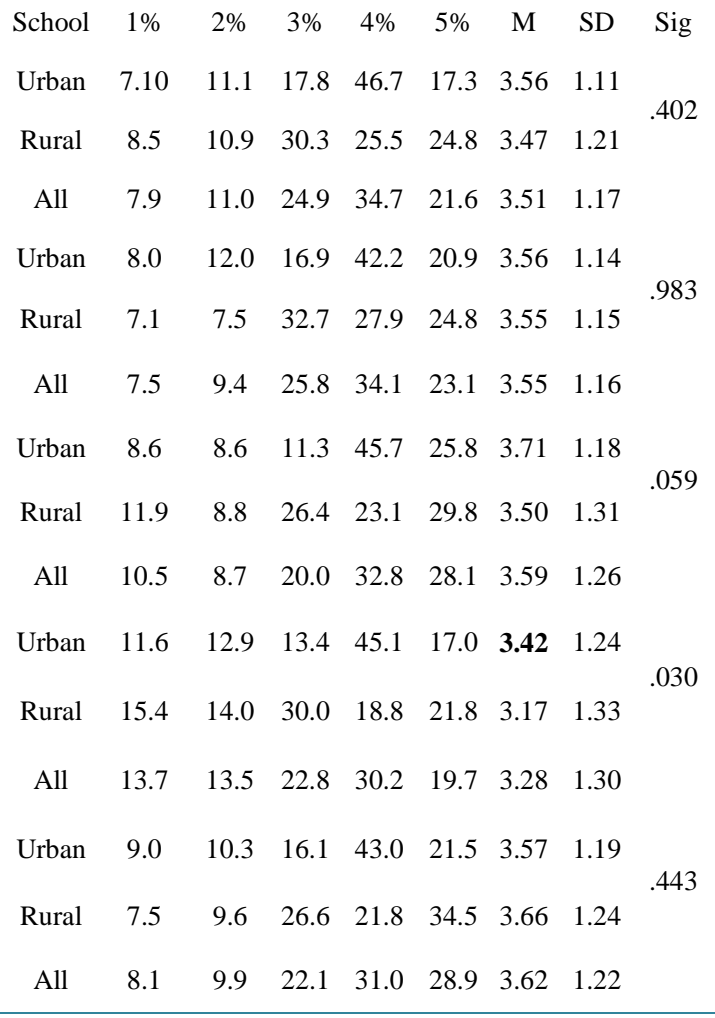




\section{Continued}

11. To think and behave like an English speaking person.

12. To read the original publications.

13. To leave Taiwan and become a member of American society.

14. To study abroad.

15. To promote educational and cultural background.

16. To pass exams.

17. To merit social recognition.

18. To travel abroad.

19. I like the countries in which English is spoken.

20. English seems of great importance today.

21. I like the English speaking people.

Instrumental Orientation (even numbers) $\begin{array}{llllllll}\text { Urban } & 14.3 & 25.4 & 16.5 & 31.7 & 12.1 & \mathbf{3 . 0 1} & 1.27\end{array}$

$\begin{array}{llllllll}\text { Rural } & 26.9 & 18.7 & 33.3 & 9.9 & 11.2 & 2.59 & 1.28\end{array}$

$\begin{array}{llllllll}\text { All } & 21.4 & 21.6 & 26.1 & 19.3 & 11.6 & 2.77 & 1.29\end{array}$

$\begin{array}{llllllll}\text { Urban } & 17.0 & 20.6 & 14.8 & 29.6 & 17.9 & 3.10 & 1.37\end{array}$

$\begin{array}{llllllll}\text { Rural } & 19.0 & 17.3 & 29.5 & 17.3 & 16.9 & 2.95 & 1.33\end{array}$

$\begin{array}{llllllll}\text { All } & 18.1 & 18.7 & 23.2 & 22.6 & 17.4 & 3.02 & 1.35\end{array}$

$\begin{array}{lllllll}\text { Urban } \quad 23.8 & 26.5 & 16.6 & 20.6 & 12.6 & 2.71 & 1.36\end{array}$

$\begin{array}{llllllll}\text { All } & 29.2 & 22.8 & 20.7 & 16.1 & 11.2 & 2.57 & 1.35\end{array}$

$\begin{array}{llllllll}\text { Urban } & 18.8 & 18.8 & 14.8 & 32.7 & 14.8 & \mathbf{3 . 0 5} & 1.36\end{array}$

$\begin{array}{llllllll}\text { Rural } & 22.4 & 18.7 & 33.0 & 10.2 & 15.6 & 2.77 & 1.33\end{array}$

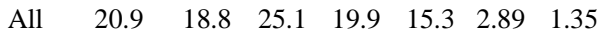

$\begin{array}{llllllll}\text { Urban } & 18.8 & 18.8 & 14.8 & 32.7 & 14.8 & 3.56 & 1.18\end{array}$

$\begin{array}{llllllll}\text { Rural } & 7.1 & 6.5 & 28.2 & 23.8 & 34.4 & 3.71 & 1.20\end{array}$

$\begin{array}{llllllll}\text { All } & 7.9 & 7.9 & 23.6 & 32.1 & 28.4 & 3.65 & 1.19\end{array}$

$\begin{array}{llllllll}\text { Urban } & 7.2 & 8.5 & 17.5 & 44.8 & 22.0 & 3.65 & 1.12\end{array}$

$\begin{array}{llllllll}\text { Rural } & 5.8 & 8.2 & 29.0 & 19.8 & 37.2 & 3.74 & 1.20\end{array}$

$\begin{array}{llllllll}\text { All } & 6.4 & 8.3 & 24.0 & 30.6 & 30.6 & 3.70 & 1.17\end{array}$

$\begin{array}{llllllll}\text { Urban } & 9.0 & 11.7 & 16.6 & 44.4 & 18.4 & 3.51 & 1.18\end{array}$

$\begin{array}{llllllll}\text { Rural } & 17.0 & 11.2 & 28.9 & 25.2 & 17.7 & 3.15 & 1.31\end{array}$

All $\quad \begin{array}{lllllll}13.5 & 11.4 & 23.6 & 33.5 & 18.0 & 3.30 & 1.27\end{array}$

$\begin{array}{llllllll}\text { Urban } & 11.2 & 13.9 & 14.3 & 39.9 & 20.6 & 3.44 & 1.27\end{array}$

$\begin{array}{llllllll}\text { Rural } & 11.6 & 16.7 & 26.2 & 18.7 & 26.9 & 3.32 & 1.33\end{array}$

All $\quad \begin{array}{lllllll}11.4 & 15.5 & 21.1 & 27.9 & 24.2 & 3.37 & 1.31\end{array}$

$\begin{array}{llllllll}\text { Urban } & 14.8 & 16.1 & 17.0 & 35.0 & 17.0 & 3.23 & 1.31\end{array}$

$\begin{array}{llllllll}\text { Rural } & 20.7 & 13.9 & 30.6 & 16.7 & 18.0 & 2.97 & 1.36\end{array}$

All $\quad \begin{array}{lllllll}18.2 & 14.9 & 24.8 & 24.6 & 17.6 & 3.08 & 1.34\end{array}$

$\begin{array}{llllllll}\text { Urban } & 8.6 & 10.4 & 15.8 & 43.7 & 21.6 & 3.59 & 1.18\end{array}$

$\begin{array}{llllllll}\text { Rural } \quad 4.8 & 6.5 & 23.0 & 24.1 & 41.6 & 3.91 & 1.15\end{array}$

$\begin{array}{llllllll}\text { All } & 6.4 & 8.2 & 19.9 & 32.6 & 32.9 & 3.77 & 1.17\end{array}$

$\begin{array}{llllllll}\text { Urban } & 13.5 & 16.7 & 21.6 & 32.0 & 16.2 & \mathbf{3 . 2 0} & 1.28\end{array}$

$\begin{array}{llllllll}\text { Rural } & 25.1 & 11.2 & 33.2 & 11.5 & 19.0 & 2.88 & 1.40\end{array}$

$\begin{array}{llllllll}\text { All } & 20.1 & 13.5 & 28.2 & 20.3 & 17.8 & 3.02 & 1.36\end{array}$

$\begin{array}{lll}\text { Urban } & \mathbf{3 . 4 6} & .83\end{array}$

$\begin{array}{llll}\text { Rural } & 3.42 & .64 & .492\end{array}$

All $\quad 3.44 \quad .76$ 


\section{Continued}

\begin{tabular}{|c|c|c|c|c|c|c|c|c|c|}
\hline \multirow{3}{*}{ Integrative Orientation (odd numbers) } & Urban & & & & & & 3.29 & .87 & \multirow{2}{*}{.002} \\
\hline & \multicolumn{6}{|l|}{ Rural } & 3.07 & .79 & \\
\hline & \multicolumn{6}{|l|}{ All } & 3.16 & .85 & \multirow{4}{*}{.050} \\
\hline \multirow{3}{*}{ Total } & \multicolumn{6}{|l|}{ Urban } & 3.38 & .80 & \\
\hline & \multicolumn{6}{|l|}{ Rural } & 3.24 & .67 & \\
\hline & \multicolumn{6}{|l|}{ All } & 3.30 & .76 & \\
\hline II. Attitude toward English Learning and Culture & School & $1 \%$ & $2 \%$ & $3 \%$ & $4 \%$ & $5 \%$ & M & SD & Sig \\
\hline \multirow{3}{*}{$\begin{array}{l}\text { 22. English is important, } \\
\text { because the people who speak it are important. }\end{array}$} & Urban & 6.8 & 15.8 & 16.2 & 37.8 & 23.4 & 3.55 & 1.20 & \multirow{3}{*}{.298} \\
\hline & Rural & 8.8 & 6.4 & 27.5 & 23.7 & 33.6 & 3.66 & 1.24 & \\
\hline & All & 7.9 & 10.4 & 22.6 & 29.8 & 29.2 & 3.61 & 1.22 & \\
\hline \multirow{3}{*}{$\begin{array}{l}\text { 23. English is an international language, } \\
\text { everyone should learn English. }\end{array}$} & Urban & 3.6 & 9.5 & 17.6 & 44.8 & 24.4 & 3.76 & 1.03 & \multirow{3}{*}{.011} \\
\hline & Rural & 5.1 & 4.4 & 21.7 & 21.0 & 47.8 & 4.02 & 1.15 & \\
\hline & All & 4.5 & 6.6 & 20.0 & 31.2 & 37.8 & 3.91 & 1.11 & \\
\hline \multirow{3}{*}{ 24. Every educated person should learn English. } & Urban & 5.8 & 11.2 & 15.7 & 45.7 & 21.5 & 3.65 & 1.11 & \multirow{3}{*}{.264} \\
\hline & Rural & 9.6 & 4.8 & 35.5 & 22.2 & 28.0 & 3.54 & 1.21 & \\
\hline & All & 7.9 & 7.6 & 26.9 & 32.4 & 25.2 & 3.59 & 1.17 & \\
\hline \multirow{3}{*}{$\begin{array}{l}\text { 25. I am not really interested in English; } \\
\text { I learn it just because it is a required course in school. }\end{array}$} & Urban & 22.6 & 20.4 & 14.5 & 25.3 & 17.2 & 2.94 & 1.43 & \multirow{3}{*}{.000} \\
\hline & Rural & 13.6 & 9.5 & 28.1 & 20.0 & 28.8 & 3.41 & 1.35 & \\
\hline & All & 17.4 & 14.1 & 22.3 & 22.3 & 23.8 & 3.20 & 1.40 & \\
\hline \multirow{3}{*}{ 26. I wish I could speak English fluently. } & Urban & 7.2 & 10.9 & 15.8 & 42.1 & 24.0 & 3.64 & 1.16 & \multirow{2}{*}{.001} \\
\hline & Rural & 7.1 & 4.7 & 17.6 & 20.7 & 49.8 & 4.01 & 1.22 & \\
\hline & All & 7.2 & 7.4 & 16.9 & 29.8 & 38.8 & 3.85 & 1.21 & \multirow{4}{*}{.204} \\
\hline \multirow{3}{*}{ 27. I hope to make friends with English speaking people. } & Urban & 9.5 & 19.9 & 21.3 & 31.7 & 17.6 & 3.28 & 1.23 & \\
\hline & Rural & 13.7 & 10.2 & 26.6 & 18.4 & 31.1 & 3.43 & 1.37 & \\
\hline & All & 11.9 & 14.4 & 24.3 & 24.1 & 25.3 & 3.36 & 1.31 & \\
\hline \multirow{3}{*}{ 28. I enjoy listening to English songs and news broadcasts. } & Urban & 15.8 & 23.1 & 17.2 & 28.5 & 15.4 & 3.04 & 1.33 & \multirow{2}{*}{.399} \\
\hline & Rural & 14.9 & 16.3 & 30.8 & 15.3 & 22.7 & 3.14 & 1.34 & \\
\hline & All & 15.3 & 19.2 & 25.0 & 20.9 & 19.6 & 3.10 & 1.33 & \multirow{4}{*}{.919} \\
\hline \multirow{3}{*}{ 29. I enjoy speaking English. } & Urban & 12.2 & 22.6 & 19.9 & 29.9 & 15.4 & 3.13 & 1.27 & \\
\hline & Rural & 14.0 & 14.0 & 33.6 & 19.9 & 18.5 & 3.14 & 1.27 & \\
\hline & All & 13.3 & 17.7 & 27.7 & 24.2 & 17.2 & 3.14 & 1.27 & \\
\hline \multirow{3}{*}{$\begin{array}{l}\text { 30. I enjoy reading English newspaper, } \\
\text { magazines, or original publications. }\end{array}$} & Urban & 16.7 & 24.9 & 19.0 & 26.2 & 13.1 & 2.94 & 1.30 & \\
\hline & Rural & 19.3 & 17.3 & 36.6 & 11.9 & 14.9 & 2.85 & 1.28 & .468 \\
\hline & All & 18.2 & 20.5 & 29.1 & 18.0 & 14.1 & 2.89 & 1.29 & \\
\hline & Urban & 12.7 & 18.6 & 17.2 & 32.6 & 19.0 & 3.26 & 1.30 & \\
\hline 31. I enjoy writing diary, letters, or compositions in English. & Rural & 13.2 & 17.3 & 29.2 & 17.3 & 23.1 & 3.19 & 1.32 & \\
\hline & All & 13.0 & 17.8 & 24.0 & 23.8 & 21.3 & 3.22 & 1.31 & \\
\hline
\end{tabular}




\section{Continued}

32. In addition to English, I want to learn an additional foreign language in the future.

33. I like to have chances to know other country's culture, so I hope to study abroad.

34. I have more difficulties in speaking and listening when I learn English.

35. Generally speaking, most

Americans are friendly, and courteous.

36. I expect to have more practical teaching material for us to learn, because I am not satisfied with the present textbook we use.

37. I expect to have teachers who are native speakers of English.

38. I hope to have more English classes in school.

39. I hope to study abroad in the summer or winter vacation.

Total

\section{Motivational Intensity}

40. If English were not taught in school, I would:

1) Not bother learning English at all.

2) Pick up English in everyday situations (i.e., read English books and newspapers, try to speak it whenever possible, etc.)

3) Try to obtain lessons in English somewhere else.

41. When I have a problem understanding something we are learning in English class, I: 1) Just forget about it.

2) Only seek help just before the exam.

3) Immediately ask the teacher for help.

42. Considering how I study English, I can honestly say that I:

1) Will pass on the basis of sheer luck or intelligence

because I do very little work. 2) Do just enough work to get along. 3) Really try to learn English.

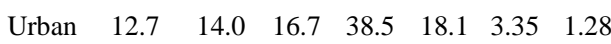

$\begin{array}{llllllll}\text { Rural } & 14.3 & 6.8 & 27.2 & 22.4 & 29.3 & 3.45 & 1.35\end{array}$

All $\quad \begin{array}{lllllll}13.6 & 9.9 & 22.7 & 29.3 & 24.5 & 3.41 & 1.32\end{array}$

$\begin{array}{llllllll}\text { Urban } & 12.7 & 18.1 & 16.7 & 35.7 & 16.7 & 3.25 & 1.28\end{array}$

$\begin{array}{llllllll}\text { Rural } & 18.7 & 11.2 & 23.8 & 18.4 & 27.9 & 3.25 & 1.44\end{array}$

$\begin{array}{llllllll}\text { All } & 16.1 & 14.2 & 20.8 & 25.8 & 23.1 & 3.25 & 1.38\end{array}$

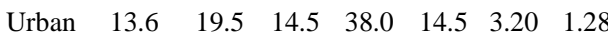

$\begin{array}{llllllll}\text { Rural } & 14.2 & 13.9 & 29.8 & 19.7 & 22.4 & 3.22 & 1.32\end{array}$

All $\quad \begin{array}{lllllll}14.0 & 16.3 & 23.3 & 27.5 & 19.0 & 3.21 & 1.30\end{array}$

$\begin{array}{llllllll}\text { Urban } & 10.0 & 13.6 & 23.5 & 33.0 & 19.9 & 3.39 & 1.22\end{array}$

$\begin{array}{llllllll}\text { Rural } & 9.5 & 10.2 & 41.4 & 21.0 & 18.0 & 3.27 & 1.15\end{array}$

$\begin{array}{llllllll}\text { All } & 9.7 & 11.6 & 33.7 & 26.2 & 18.8 & 3.32 & 1.18\end{array}$

$\begin{array}{llllllll}\text { Urban } & 14.0 & 18.6 & 23.5 & 25.3 & 18.6 & 3.15 & 1.31\end{array}$

$\begin{array}{llllllll}\text { Rural } & 19.4 & 13.6 & 42.5 & 11.9 & 12.6 & 2.84 & 1.23\end{array}$

All $\quad \begin{array}{lllllll}17.1 & 15.7 & 34.4 & 17.7 & 15.1 & 2.98 & 1.27\end{array}$

$\begin{array}{llllllll}\text { Urban } & 9.0 & 17.2 & 20.8 & 33.9 & 19.0 & 3.36 & 1.22\end{array}$

$\begin{array}{llllllll}\text { Rural } & 8.1 & 8.1 & 23.7 & 18.3 & 41.7 & 3.77 & 1.29\end{array}$

All $\quad \begin{array}{lllllll}8.5 & 12.0 & 22.5 & 25.0 & 32.0 & 3.59 & 1.27\end{array}$

$\begin{array}{llllllll}\text { Urban } & 10.4 & 13.6 & 22.2 & 32.1 & 21.7 & 3.41 & 1.25\end{array}$

$\begin{array}{llllllll}\text { Rural } & 12.3 & 9.2 & 28.4 & 19.5 & 30.5 & 3.46 & 1.33\end{array}$

$\begin{array}{llllllll}\text { All } & 11.5 & 11.1 & 25.7 & 25.0 & 26.7 & 3.44 & 1.30\end{array}$

$\begin{array}{llllllll}\text { Urban } & 12.2 & 14.5 & 17.6 & 33.9 & 21.7 & 3.38 & 1.30\end{array}$

$\begin{array}{llllllll}\text { Rural } & 11.2 & 5.8 & 24.1 & 14.2 & 44.7 & 3.75 & 1.36\end{array}$

$\begin{array}{llllllll}\text { All } & 11.6 & 9.5 & 21.3 & 22.7 & 34.9 & 3.59 & 1.35\end{array}$

Urban

Rural

All

School $\quad 1 \% \quad 2 \% \quad 3 \%$

Urban $\quad 22.6 \quad 47.5 \quad 29.9$

$\begin{array}{llllll}\text { Rural } & 22.4 & 42.0 & 35.6 & 2.13 & .75\end{array}$

$\begin{array}{llllll}\text { All } & 22.5 & 44.4 & 33.1 & 2.11 & .74\end{array}$

$\begin{array}{llllll}\text { Urban } & 14.0 & 22.1 & 64.0 & 2.50 & .72\end{array}$

$\begin{array}{llllll}\text { Rural } & 7.1 & 12.9 & 80.0 & 2.72 & .58\end{array}$

$\begin{array}{llllll}\text { All } & 10.1 & 16.8 & 73.1 & 2.63 & .65\end{array}$

$\begin{array}{llllll}\text { Urban } & 11.8 & 37.6 & 50.7 & 2.38 & .68\end{array}$

$\begin{array}{llllll}\text { Rural } & 15.6 & 31.2 & 53.2 & 2.37 & .74\end{array}$

$\begin{array}{llllll}\text { All } & 14.0 & 33.9 & 52.1 & 2.38 & .71\end{array}$
$3.32 \quad .83$

$3.41 \quad .62$

$3.37 \quad .77$

M SD sig

$2.08 \quad .74$ 


\section{Continued}

43. When it comes to English homework, I:

1) Just skim over it. 2) Put some effort into it,

but not as much as I could. 3) Work very carefully,

making sure I understand everything.

44. I actively think about what I have learned in my English class:

1) Hardly ever. 2) Once in a while. 3) Very frequently.

45. When I am in English class, I: 1) Never say anything.

2) Answer only the easier questions.

3) Volunteer answers as much as possible.

46. If my teacher wanted someone to do an extra English assignment,

I would: 1) Definitely not volunteer.

2) Only do it if the teacher asked me directly.

3) Definitely volunteer.

47. After I get my English assignments back, I:

1) Just throw them in my desk and forget them.

2) Look them over, but don't bother correcting mistakes.

3) Always read carefully, or rewrite them, correcting my mistakes.

48. When I hear an English song on the radio, I:

1) Change the station. 2) Listen to the music,

paying attention only to the easy words.

3) Listen carefully and try to understand all the words.

49. If there were a local English TV station, I would:

1) Never watch it. 2) Turn it on occasionally.

3) Try to watch it often.

\begin{tabular}{|c|c|c|c|c|c|c|}
\hline Urban & 13.1 & 33.0 & 53.9 & 2.40 & .71 & \multirow{2}{*}{.095} \\
\hline Rural & 7.5 & 34.4 & 58.2 & 2.50 & .63 & \\
\hline All & 9.9 & 33.8 & 56.3 & 2.46 & .66 & \multirow{4}{*}{.000} \\
\hline Urban & 14.9 & 46.2 & 38.9 & 2.23 & .69 & \\
\hline Rural & 20.7 & 58.5 & 20.7 & 2.00 & .64 & \\
\hline All & 18.3 & 53.2 & 28.5 & 2.10 & .67 & \\
\hline Urban & 11.3 & 39.6 & 49.1 & 2.37 & .68 & \multirow{2}{*}{.144} \\
\hline Rural & 6.8 & 40.1 & 53.1 & 2.46 & .62 & \\
\hline All & 8.7 & 39.9 & 51.4 & 2.42 & .64 & \multirow{4}{*}{.243} \\
\hline Urban & 14.0 & 31.5 & 54.5 & 2.40 & .72 & \\
\hline Rural & 8.5 & 35.4 & 56.1 & 2.47 & .64 & \\
\hline All & 10.9 & 33.7 & 55.4 & 2.44 & .68 & \\
\hline Urban & 5.4 & 29.9 & 64.7 & 2.59 & .59 & \multirow{2}{*}{.031} \\
\hline Rural & 6.1 & 17.3 & 76.6 & 2.70 & .57 & \\
\hline All & 5.8 & 22.7 & 71.5 & 2.65 & .58 & \multirow{4}{*}{.642} \\
\hline Urban & 27.1 & 27.6 & 45.2 & 2.18 & .83 & \\
\hline Rural & 30.8 & 23.7 & 45.4 & 2.14 & .86 & \\
\hline All & 29.3 & 25.4 & 45.3 & 2.16 & .84 & \\
\hline Urban & 18.6 & 45.5 & 35.9 & 2.17 & .71 & \multirow{2}{*}{.002} \\
\hline Rural & 22.4 & 56.9 & 20.7 & 1.98 & .65 & \\
\hline All & 20.8 & 52.0 & 27.2 & 2.06 & .69 & \multirow{4}{*}{.006} \\
\hline Urban & & & & 2.43 & .49 & \\
\hline Rural & & & & 2.54 & .36 & \\
\hline All & & & & 2.50 & .45 & \\
\hline
\end{tabular}

Chinese version with phonetic symbols of the questionnaire items 6 - 49 were mostly adopted from Gardner's "Social psychology and second language learning: The role of attitude and motivation” (1985). 